\title{
Quantitative content of flavonoids in plant samples from the Crimean population of oregano (Origanum vulgare)
}

\author{
A.V. Mishnev, E.F. Myagkikh*, and I.V. Belova \\ FSBSI "Research Institute of Agriculture of Crimea" 150, Kievskaya str., Simferopol, Republic of \\ Crimea, 295453, Russia
}

\begin{abstract}
The aim of the research was to analyze the quantitative content of flavonoids in raw oregano (Origanum vulgare L.) from indigenous flora from different geographical locations of the Crimean peninsula. The objectives of the research included: the selection of promising samples for breeding, conclusion on the potential use of raw materials collected from regional indigenous populations for medical purposes. It was found that the raw oregano material in most cases did not conform to the requirements of the pharmacopoeial monograph RF XIV in terms of the total flavonoids content equivalent to luteolin and can not be recommended for use as an official raw material. The total content of flavonoids in herbal raw materials varied from 0.40 to $1.05 \%$ with an average value of $0.69 \%$. Only three of the tested samples exceeded the threshold of $0.80 \%$, with $0.81-1.05 \%$ value, one sample had this index at the level of the lower threshold, $0.80 \%$. No high-flavonoid samples that would be valuable as donors of this trait for breeding varieties of medicinal direction have been identified. The conclusion was made that it is advisable to grow high-flavonoid varieties specially created for this purpose instead of collecting oregano herbal materials in their natural habitat.
\end{abstract}

\section{Introduction}

Oregano (Origanum vulgare L.) is a perennial herbaceous plant of the Mint family (Lamiaceae Martinov.). Turkey is considered the center of origin of the species of the genus Origanum, considering the species diversity in this area, most of which are endemics $[1,2]$. Oregano is distributed in Western and Eastern Europe, in the mountainous regions of Central Asia, the Caucasus, Kazakhstan, southern Siberia, Primorye, the Amur region; as an adventitious plant plant it occurs in the Russia's Far East. Its area in Europe spreads from south to north from the Mediterranean to Norway, and in West Asia it reaches the Himalayas. In the Russian Federation, oregano grows throughout the European part, in Siberia, in the Far East, except for the Arctic regions [3]. The raw material is used in food, canning industry or liqueur production. "Oregano" spice is widely known. It should be noted that for its preparation the aerial parts of plants of $O$. onites L. species (trade name Turkish oregano)

\footnotetext{
* Corresponding author: origanum.science@mail.ru
} 
and $O$. vulgares sp. hirtum (Link) Ietsw. (Greek oregano) are used in the Mediterranean. The raw material of $O$. vulgare is widely used in cooking, herbal teas in places of its natural habitat, but not as widely as "Oregano". The plants of this species are used to produce an essential oil known as "hop oil", and its component composition may vary greatly due to the chemotypic variability common to this species [4-9]. Oregano essential oil is used to fragrance perfumes and cosmetics $[4,10]$.

Numerous publications demonstrate the economic viability of using raw materials of wild O. vulgare due to its high price, resulting from its unique qualities or ecological purity, etc. In Turkey, for example, about 10,000 tons of dry raw material of wild oregano species, mainly $O$. onites and others, are harvested annually, with thymol and/or carvacrol dominating in their essential oils. A part of raw materials is used domestically, but the remaining significant part is exported. Wild carvacrol (thymol) oregano raw material is harvested in Albania (about 600 tons) and Greece. It is noted that raw materials of wild $O$. vulgare are harvested in Hungary [11]. A survey of the wild population of oregano for industrial harvesting was conducted in Tajikistan. It was concluded that such harvesting is possible in certain areas of the republic [12]. In the Samara region of Russia the analysis was carried out to determine the feasibility of harvesting wild raw materials of oregano [13]. In the KarachayCherkess Republic of Russia, a conclusion about the suitability of oregano thickets for industrial-scale use was made [14]. The preparations derived from oregano raw materials normalize the breakdown of lipids, have antispasmodic, secretolytic, coating, choleretic, analgesic, cicatrizing, antimicrobial, antioxidant, styptic and expectorant effects; they are used against insomnia, nervous disorders and as an anticonvulsant [15-18]. The essential oil is used in medicine externally for compresses and aromatic baths as an analgesic, and internally as a stomachic, in traditional medicine it is used against toothache [19].

Recently, interest in flavonoids has increased and studies have appeared proving the importance of these compounds for a human organism. Firstly, they can regulate the permeability of blood vessel walls, improve their elasticity, and prevent sclerotic lesions. Also, flavonoids have an antioxidant effect by neutralizing free radicals. The ability of flavonoids to protect human tissue from histamine emissions provides additional options for treating allergies and asthma. Flavonoid-containing plants are considered to be a numerous and most popular group of plants both in Russian and in world medicine [10,20]. Waterethanol extracts of oregano contain flavonoids (luteolin, luteolin-7-glucuronide, cosmosine, chrysin-7-glucuronide, 5-oxyflavone, naringin, etc.), anthocyanins, phenolcarboxylic acids (caffeic, chlorogenic, vanillic), tannins $[21,22]$. It was reported that galangin and quercetin found in Origanum species have a specific antimutagenic effect and activity against food carcinogens [23].

It was found that two classes of flavonoids are known for this genus: free flavonoids and flavonoid glycosides [24]. Qualitative and quantitative composition of flavonoids in $O$. vulgare was investigated in detail by Mirovich V.M. et al. They found that the qualitative composition of flavonoids of wild and cultivated specimens of oregano is the same, and most of them are accumulated in the leaves and inflorescences. Flavonoid content in the stems is very low. The authors argue that oregano plants grown in Eastern Siberia do not differ in their flavonoid content from wild specimens of the European part of the Russian Federation and Siberia. It was reported that domestication increases the quantitative content of flavonoids compared to wild specimens of the same region $[21,25,26]$. Since $O$. vulgare is an official plant, the herb (Origani vulgaris herba) is used as a medicinal raw material, there are two normative documents regulating the quantitative content of the medicinal components of raw materials, the State Pharmacopoeia of the Russian Federation XIV (SF RF XIV) and GOST for oregano herb [27, 28]. These two documents differ slightly in their requirements for the content of the sum of flavonoids in terms of luteolin: Pharmacopoeia defines the lower limit of this indicator at $0.8 \%$, while GOST requirements of at least $1.0 \%$. 
There are reports in the literature about the selection of common oregano samples with a very high content of flavonoids in the raw material. For example, researchers from Armenia stated that they analyzed four samples of wild oregano with a total flavonoid content in terms of luteolin in the range of 3.4-3.8\% [29]. Such a high values make the samples valuable not only for medicinal use, but also for breeding purposes.

The Crimean Peninsula is territorially located close to Turkey, where the greatest species diversity of the Origanum genus is observed [1,2]. In addition, during the Crimean Khanate there were close economic and military contacts between Crimea and Turkey, accompanied by the transfer of large amounts of goods and people (traders, military, etc.). An opinion exists that up to half of the modern flora of the Crimea is from the Mediterranean area [30]. However, the species affiliation of oregano of the Crimean flora is determined by one species $O$. vulgare. Opinions have been expressed at different times about the growth of other species, and the separation of a special Crimean subspecies $([19,31,32]$, but the results of the latest revision of the Crimean flora, conducted by AV Yena, there is only one species of oregano in the Crimean peninsula, O. vulgare [30].

In Crimea, oregano grows everywhere on forest edges, glades, grassy slopes, mountain plateaus in the Piedmont, the Crimean Mountains, and the South Coast [31]. Usually it does not form continuous thickets, growing in cenopopulations with other herbaceous species. Different growth conditions contribute to the formation of ecotypes and ecads that differ greatly morphologically. The authors of the article monitor the volume of cultivation of raw materials of aromatic and medicinal plants in the course of their work. There is no reliable statistics about the cultivation of oregano in the Russian Federation. It is mentioned that the main harvesting (apparently, this refers to the harvesting of wild-growing raw materials - The authors' comment) takes place in the European part of the country [20, p.30]. There is also little information about the commercial cultivation of oregano in the Crimea. From various sources, the authors are aware that oregano is grown in small quantities by enterprises engaged in the production of medicinal or (and) essential oil raw materials. The species composition and origin of the seeds are usually unknown. In addition, there is a network of enterprises that harvest wild raw materials or buy them up from the local residents. In this regard, it is possible that the composition of herbal mixtures, teas, pads and other therapeutic and preventive products produced in the Crimea containing raw materials of $O$. vulgare, includes wild oregano herb.

In FSBSI "Research Institute of Agriculture of Crimea" researches are conducted on breeding oregano mainly for the purpose of obtaining essential oil. The features of seed and vegetative reproduction, productivity and cultivation of this species were studied. A method of propagation by herbaceous cuttings has been developed [15]. Technological charts for cultivation of this species have been compiled and published based on the research materials [35]. Thus, a scientific and practical basis for the cultivation of oregano on industrial scale was created.

The aim of the research was to analyze the quantitative content of flavonoids in oregano plants from indigenous flora from different geographical locations of the Crimean Peninsula. The objectives of the research included: harvesting samples of oregano raw material, analysis of the quantitative content of flavonoids, comparison with the requirements of GOST and Pharmacopoeia monograph for oregano raw material and the selection of promising samples for breeding, the conclusion about the prospects of using wild-growing raw materials of the region for medicinal purposes.

\section{Materials and Methods}

The research was carried out in 2018-2019. Raw material of oregano, collected from different places of the Crimean Peninsula was used as a study material (Table 1). Plant 
material was cut with secateurs in the full blossom phase. The raw material was dried in a well-ventilated room until the moisture content was no more than $13 \%$. Then quantitative determination of flavonoids in terms of luteolin was performed according to the method of the State Pharmacopoeia of the Russian Federation (XIV edition) [27].

Table 1. Places of harvesting of $O$. vulgare plant samples, 2018-2019.

\begin{tabular}{|c|c|c|c|c|}
\hline $\begin{array}{l}\text { № } \\
\text { П.П. }\end{array}$ & Sampling area & $\begin{array}{l}\text { GPS } \\
\text { position* }\end{array}$ & $\begin{array}{l}\text { Altitude above } \\
\text { sea-level, m }\end{array}$ & Notes \\
\hline 1 & $\begin{array}{l}\text { Vicinity of the Angarskyi Pass, a forest glade, } \\
\text { the Main Ridge of the Crimean Mountains }\end{array}$ & $\begin{array}{l}44^{\circ} 45^{\prime} 17^{\prime \prime} \mathrm{N} 3 \\
4^{\circ} 20^{\prime} 14^{\prime \prime} \mathrm{E}\end{array}$ & 817 & \\
\hline 2 & $\begin{array}{l}\text { Angarskyi Pass, vicinity of Lake } \\
\text { Kutuzovskoye, the Main Ridge of the Crimean } \\
\text { Mountains }\end{array}$ & $\begin{array}{l}44^{\circ} 44^{\prime} 23.2^{\prime \prime} \mathrm{N} \\
34^{\circ} 20^{\prime} 07.8^{\prime \prime} \mathrm{E}\end{array}$ & 872 & \\
\hline 3 & $\begin{array}{l}\text { Tavelchuk gully, vicinity of the Krasnolesye } \\
\text { village, the Main Ridge of the Crimean } \\
\text { Mountains }\end{array}$ & $\begin{array}{l}44^{\circ} 48^{\prime} 02.5^{\prime \prime} \mathrm{N} \\
34^{\circ} 13^{\prime} 51.9^{\prime \prime} \mathrm{E}\end{array}$ & 548 & \\
\hline 4 & $\begin{array}{l}\text { Vicinity of Mount Elkh-Kaya (southern slope), } \\
\text { the Main Ridge of the Crimean Mountains }\end{array}$ & $\begin{array}{l}44^{\circ} 45^{\prime} 35^{\prime \prime} \mathrm{N} \\
34^{\circ} 21^{\prime} 17.6^{\prime \prime} \mathrm{E}\end{array}$ & 833 & \\
\hline 5 & $\begin{array}{l}\text { Kazu-Kaya Mountain (the southern slope of } \\
\text { Eklizi-Burun Mountain), the Main Ridge of the } \\
\text { Crimean Mountains }\end{array}$ & $\begin{array}{l}44^{\circ} 43^{\prime} 51^{\prime \prime} \mathrm{N} \\
34^{\circ} 18^{\prime} 20.5^{\prime \prime} \mathrm{E}\end{array}$ & 1083 & \\
\hline & $\begin{array}{l}\text { Saurgan Glade, southern slope, the Main Ridge } \\
\text { of the Crimean Mountains: }\end{array}$ & & & \multirow{4}{*}{$\begin{array}{c}\text { Samples were } \\
\text { taken from } \\
\text { plants clusters } \\
\text { that were } \\
\text { morphologicall } \\
\text { y and } \\
\text { organolepticall } \\
\text { y different from } \\
\text { each other } \\
\end{array}$} \\
\hline $6 \mathrm{~A}$ & & $\begin{array}{l}44^{\circ} 43^{\prime} 41^{\prime \prime} \mathrm{N} \\
34^{\circ} 18^{\prime} 09.1^{\prime \prime} \mathrm{E}\end{array}$ & 976 & \\
\hline $6 \mathrm{~B}$ & & $\begin{array}{l}44^{\circ} 43^{\prime} 42.2^{\prime \prime} \mathrm{N} \\
34^{\circ} 18^{\prime} 06.4^{\prime \prime} \mathrm{E}\end{array}$ & 985 & \\
\hline $6 \mathrm{C}$ & & $\begin{array}{l}44^{\circ} 43^{\prime} 36.6^{\prime \prime} \mathrm{N} \\
34^{\circ} 18^{\prime} 09.7^{\prime \prime} \mathrm{E}\end{array}$ & 952 & \\
\hline 7 & $\begin{array}{l}\text { North Demerdzhi Mountain, northern slope, } \\
\text { the Main Ridge of the Crimean Mountains }\end{array}$ & $\begin{array}{l}44^{\circ} 47^{\prime} 43.0^{\prime \prime} \mathrm{N} \\
34^{\circ} 24^{\prime} 20.7^{\prime \prime} \mathrm{E}\end{array}$ & 1189 & \\
\hline 8 & $\begin{array}{l}\text { North Demerdzhi Mountain, northern slope, } \\
\text { the Main Ridge of the Crimean Mountains }\end{array}$ & $\begin{array}{l}44^{\circ} 47^{\prime} 30.0^{\prime \prime} \mathrm{N} \\
34^{\circ} 23^{\prime} 49.3^{\prime \prime} \mathrm{E}\end{array}$ & 1210 & \\
\hline 9 & $\begin{array}{l}\text { Vicinity of the Kolkhoznoye village, } \\
\text { Baydarskaya Valley, the Main Ridge of the } \\
\text { Crimean Mountains }\end{array}$ & $\begin{array}{l}44^{\circ} 28^{\prime} 47.6^{\prime \prime} \mathrm{N} \\
33^{\circ} 53^{\prime} 07.4^{\prime \prime} \mathrm{E}\end{array}$ & 387 & \\
\hline 10 & $\begin{array}{l}\text { Krasnaya Gully, Ak-Kaya Mountain (White } \\
\text { Rock), the Inner Ridge of the Crimean } \\
\text { Mountains }\end{array}$ & $\begin{array}{l}45^{\circ} 06^{\prime} 55.2^{\prime \prime} \mathrm{N} \\
34^{\circ} 36^{\prime} 36.2^{\prime \prime} \mathrm{E}\end{array}$ & 167 & \\
\hline 11 & $\begin{array}{l}\text { Vicinity of the Kholmovka village, northwest } \\
\text { slope, the Inner Ridge of the Crimean } \\
\text { Mountains }\end{array}$ & $\begin{array}{l}44^{\circ} 39^{\prime} 38.7^{\prime \prime} \mathrm{N} \\
33^{\circ} 46^{\prime} 19.4^{\prime \prime} \mathrm{E}\end{array}$ & 94 & \\
\hline 12 & $\begin{array}{l}\text { Bakla area, southern slope, the Inner Ridge of } \\
\text { the Crimean Mountains }\end{array}$ & $\begin{array}{l}44^{\circ} 49^{\prime} 31.5^{\prime \prime} \mathrm{N} \\
33^{\circ} 59^{\prime} 51.2^{\prime \prime} \mathrm{E}\end{array}$ & 270 & \\
\hline 13 & $\begin{array}{l}\text { Vicinity of the Lake Krugloye, Zaprudnoye } \\
\text { village, the Southern Coast of Crimea }\end{array}$ & $\begin{array}{l}44^{\circ} 36^{\prime} 10.8^{\prime \prime} \mathrm{N} \\
34^{\circ} 19^{\prime} 23.8^{\prime \prime} \mathrm{E}\end{array}$ & 470 & $\begin{array}{l}\text { white- } \\
\text { flowered } \\
\text { form }\end{array}$ \\
\hline 14 & $\begin{array}{l}\text { Vicinity of the Lake Krugloye, Zaprudnoye } \\
\text { village, the Southern Coast of Crimea }\end{array}$ & $\begin{array}{l}44^{\circ} 36^{\prime} 10.6^{\prime \prime} \mathrm{N} \\
34^{\circ} 19^{\prime} 23.8^{\prime \prime} \mathrm{E}\end{array}$ & 469 & \\
\hline
\end{tabular}

* GPS position was determined on the website earth.google.com

\section{Results and Discussion}

The laboratory studies revealed that the total amount of flavonoids in the plant raw materials of the studied samples of $O$. vulgare was in the range of $0.40-1.05 \%$ with an average value of $0.69 \%$ (Table 2 ). Only three of the tested samples significantly exceeded the threshold of $0.8 \%$ according to the requirements of SF RF XIV, being from 0.81 to $1.05 \%$ (samples $6 \mathrm{~A}$; 
$6 \mathrm{~B} ; 7$ ), two samples had this index at the lower limit, being $0.80 \%$ (samples $1 ; 8$ ). We have not identified any high-flavonoid samples that would be valuable as donors of this trait in directed breeding to create varieties of medicinal direction.

Two samples of oregano herb with the total amount of flavonoids compliant with GOST $21908-93$, sample 6 A ( $0.97 \%$ of flavonoids) and sample 7 (1.05\% of flavonoids), were detected.

Table 2. Results of quantitative determination of total

flavonoids content in oregano raw material, 2018-2019.

\begin{tabular}{|c|c|c|c|}
\hline Sample number & Moisture content, $\%$ & $\begin{array}{c}\text { Mass fraction of } \\
\text { flavonoids in terms of } \\
\text { luteolin, } \%\end{array}$ & Year of analysis \\
\hline 1 & $8.9 \pm 0.10$ & $0.81 \pm 0.02$ & 2018 \\
\hline 2 & $7.9 \pm 0.45$ & $0.40 \pm 0.01$ & 2018 \\
\hline 3 & $5.6 \pm 0.00$ & $0.40 \pm 0.04$ & 2018 \\
\hline 4 & $9.2 \pm 0.20$ & $0.63 \pm 0.06$ & 2018 \\
\hline 5 & $8.8 \pm 0.80$ & $0.77 \pm 0.02$ & 2019 \\
\hline \multirow[t]{2}{*}{$6 \mathrm{~A}$} & $6.8 \pm 0.00$ & $0.96 \pm 0.01$ & 2018 \\
\hline & $10.2 \pm 0.20$ & $0.97 \pm 0.01$ & 2019 \\
\hline $6 \mathrm{~B}$ & $8.7 \pm 0.30$ & $0.82 \pm 0.0$ & 2018 \\
\hline \multirow[t]{2}{*}{$6 \mathrm{C}$} & $8.3 \pm 0.30$ & $0.66 \pm 0.02$ & 2018 \\
\hline & $10.2 \pm 0.20$ & $0.69 \pm 0.00$ & 2019 \\
\hline 7 & $10.2 \pm 0.80$ & $1.05 \pm 0.08$ & 2019 \\
\hline 8 & $10.3 \pm 0.10$ & $0.80 \pm 0.04$ & 2019 \\
\hline 9 & $9.7 \pm 0.30$ & $0.67 \pm 0.04$ & 2019 \\
\hline 10 & $7.7 \pm 0.30$ & $0.65 \pm 0.03$ & 2018 \\
\hline 11 & $8.0 \pm 0.00$ & $0.63 \pm 0.03$ & 2018 \\
\hline 12 & $8.5 \pm 0.10$ & $0.49 \pm 0.03$ & 2018 \\
\hline 13 & $8.5 \pm 0.50$ & $0.62 \pm 0.07$ & 2018 \\
\hline 14 & $8.7 \pm 0.30$ & $0.60 \pm 0.05$ & 2018 \\
\hline Mean & & $0.69 \pm 0.04 *$ & \\
\hline $\begin{array}{l}\text { Pharmacopoeial } \\
\text { monograph } \\
\text { requirements }\end{array}$ & & not less than $0.8 \%$ & \\
\hline
\end{tabular}

* excluding repeated analysis of samples 6A and 6C in 2019.

In 2018, three samples of oregano were harvested from the Saurgan glade (sampling point 6). This large glade is located on the southern slope of the Main Ridge of the Crimean Mountains under the Eklizi-Burun peak (Chatyr-Dag Mountain). In this area, samples were taken from different locations (forest edge, open slope) with contrasting morphological differences and different aroma due to the component composition of the plants essential oil. According to the results of the analysis, two out of three samples (6A and 6B) exceeded the lower pharmacopoeial limit for the total flavonoid content (Table 3).

In order to evaluate the stability of total amount of flavonoids in the raw material over the years, the raw material of samples $6 \mathrm{~A}$ and $6 \mathrm{C}$ was reharvested in 2019 . It was found that in different years the values were very close: 0.96 and $0.97 \%$ for sample $6 \mathrm{~A}$ and 0.66 and $0.69 \%$ for sample $6 \mathrm{C}$, which allows us to conclude that this trait is stable over the years.

For all raw oregano sampling areas, no regularities concerning the dependence of the flavonoid's accumulation on the geographical location (the Inner or the Main Ridge of the Crimean Mountains, the Southern Coast of Crimea), the altitude above sea level, the exposure of the slope etc. were revealed. In addition, no contrasting differences in ecotypes (ecads) of 
oregano growing on forest edges or forest glades, on open slopes, on rocky mountain plateaus, etc. were found.

Thus, the results of the analysis of wild-growing oregano raw material (16 samples) harvested from various geographical locations on the Crimean Peninsula (14 sampling sites) showed that in most cases the total flavonoid content of raw materials does not conform to the requirements of SF RF XIV. It does not conform to the standard requirement of the pharmacopoeial monograph PM.2.5.0012.15 for this parameter for raw materials intended for obtaining water, alcohol, alcohol-water extracts [27]. Consequently, the harvesting of wild-growing oregano raw material in the Crimea may not be recommended for obtaining official raw materials.

\section{Conclusions}

1. The analysis of raw oregano harvested from different areas of the Crimean Peninsula showed that the total flavonoids content in terms of luteolin in raw material in most cases does not conform to the requirements of pharmacopoeial monograph PM.2.5.0012.15 and can not be recommended for use as an official raw material.

2. No contrasting differences in total flavonoids content in oregano raw material were found depending on the geographical location of sampling points or on the belonging of the analyzed samples to different ecotypes (ecads).

3. High-flavonoid wild samples that can serve as donors in the breeding of oregano varieties suitable for obtaining official raw material were not found.

4. As an alternative to the collection of medicinal raw materials of oregano in wild populations, it is advisable to cultivate high-flavonoid varieties that have been specially created for this purpose.

\section{References}

1. K. Hüsnü Can Baser, Pure Appl. Chem., 74 (4), 527-545 (2002) DOI:10.1351/pac2002 74040527

2. K. Husnu Can Baser, The Turkish Origanum species. Oregano. The genera Origanum and Lippia, 109-126 (Agricultural University of Athens, Athens, Greece, London and New York, Medicinaland Aromatic Plants - Industrial Profiles, 2002)

3. D.O. Bokov, S.L. Morokhina, N.V. Pyatigorskaya, D.M. Popov, Butlerovskiye soobscheniya, 35 (7), 94-101 (2013) (in Russian)

4. S.A. Voytkevich, Essential oils for perfumery and aromatherapy, 79-80 (Moscow, Pischevaya Promyshlennost', 1999) (in Russian)

5. D. Mockutë, A. Judpentienë, G. Bernotienë, CHEMIJA, 15 (1), 33-37 (2004) DOI: $10.4103 / 0974-8490.81964$

6. M. Vasinauskienè, J. Radušienė, I. Zitikaitė, E. Survilienè, Agronomy Research 4(Special issue), 437-440 (2006)

7. A.A. Alyakin, A.A. Efremov, S.V. Lagin, O.O. Danilova, Khimija Rastitel'nogo Syr'ja 1, 99-104 (2010) (in Russian)

8. M.A. Myadelets, D.V. Domrachev, V.A. Cheremushkina, Khimija Rastitel'nogo Syr'ja, 1, 111-117 (2012) (in Russian)

9. F.M. Khazieva, V.I. Osipov, I.N. Korotkikh, Khimija Rastitel'nogo Syr'ja 4, 97-105 (2016) (in Russian) 
10. WHO monographs on medicinal plants commonly used in the Newly Independent States (NIS), 291-304 (World Health Organization, 2010)

11. Oregano. The genera Origanum and Lippia, 267 (Agricultural University of Athens, Athens, Greece. London and New York. Medicinal and Aromatic Plants - Industrial Profiles, 2002)

12. D.S. Sattarov, Resources of essential-oil medicinal plants in some areas of the southern slope of the Gissar Ridge of Tajikistan, 144 (Ph.D. thesis in Biology, Dushanbe, 2010) (in Russian)

13. V.A. Kurkin, A.V. Kurkina, A.I. Husainova, T.K. Ryazanova, O.V. Sazonova, Bashkortostan Medical Journal, 13, 2(74), P.44-47 (2018) (in Russian)

14. F.A. Tambieva, The Lamiaceae Lindl. in flora of the Karachaevo-Cherkessk Republic and prospects for their economic use, 117 (Ph.D. thesis in Biology, Karachaevsk, 2005) (in Russian)

15. E.F. Miagkikh, Morpho-biological features and economically valuable characteristics of Origanum vulgare L. in the Piedmont zone of the Crimea in relation to the breeding objectives, 24 (extended abstract of Ph.D. thesis in Biology, Krasnodar, 2015)

16. N.S. Jagtap, R.V. Wagh, M.K. Chatli, et. al., Agric. Res. (2020) https://doi.org/10.10 07/s40003-020-00464-5

17. B. Teixeira, A. Marques, C. Ramos, C. Serrano, O. Matos, N.R. Neng, J.M.F. Nogueira, J.A. Saraiva, M.L. Nunes, J. Sci. Food Agric. 93, 2707-2714 (2013) DOI:10.1002 / jsfa.6089

18. R. Pezzani, S. Vitalini, M. Iriti, Phytochemistry Reviews 16 (6), 1253-1268 (2017) DOI:10.1007/s11101-017-9535-Z

19. M.I. Goryaev, Essential oils of the flora of the USSR, 166-168 (Alma-Ata: Publishing House of the Academy of Sciences of the Kazakh SSR, 1952) (in Russian)

20. D.N. Petrova, Improvement of analysis methods of some flavonoid-containing plants, 149 (Ph.D. thesis in Pharmaceutical Sciences, Kazan, 2015) (in Russian)

21. V.M. Mirovich, Pharmacognostic study of representatives of genera Origanum L. and Rhododendron L. from Eastern Siberia flora, 42 (extended abstract of Ph.D. thesis in Pharmacy, Ulan-Ude, 2010) (in Russian)

22. D.O. Bokov, The use of Origanum vulgare L. and Origanum monites L. in the treatment of malignant tumors: mechanisms of antitumor activity of phenolic compounds, $V$ International Student Scientific Conference. Student Scientific Forum-2013. https://scienceforum.ru/2013/article/2013006463. Accessed at 10.09.2020 (in Russian)

23. K. Kanazava, H. Kawasaki, K. Samejima, Ashida, Danno G. Specific desmutagens (antimutagens) in Oregano against dietary carcinogen, Trp-P-2, are galangin and quercetin // J. Agric. Food Chem.1995. 43(2). Pp.404-419. DOI: 10.1021 / bk-20070946. ch004

24. D. Barǐcevǐc, T. Bartol, The biological/pharmacological Oregano. The genera Origanum and Lippia, 177-213 (Agricultural University of Athens, Athens, Greece, London and New York. Medicinal and Aromatic Plants - Industrial Profiles, 2002)

25. V.A. Peshkova, V.M. Mirovich, Khimiya prirodnih soedinenii, 4, 522 (1984) (in Russian)

26. V.M. Mirovich, Resursovedcheskoje i farmacognosticheskoje izuchenije lekarstvennoj flory SSSR. Moscow 25, 105-109 (1987) (in Russian)

27. State Pharmacopoeia of the Russian Federation, PM.2.5.0012.15 Oregano herb, 391401 (Moscow: Edition XIII. Vol.III., 2015) (in Russian) 
28. GOST 21908-93 Interstate Standard. Oregano herb. Specifications. Interstate Council for Standardization, Metrology and Certification. Minsk. 10 p. (in Russian)

29. A.V. Mogrovyan, Biological Journal of Armenia, 3(65), 28-32 (2013) (in Armenian)

30. A.V. Yena, Natural flora of the Crimean peninsula: a monograph, 232 (Simferopol: N. Orianda, 2012) (in Russian)

31. E.V. Wolf, Flora of the Crimea, 2, 201-204 (Moscow: Kolos, 1966) (in Russian)

32. A Definitive Guide of Higher Plants of the Crimea, A group of authors under the general editorship of N.I. Rubtsov, 550 (Leningrad, Nauka, 1972) (in Russian)

33. Flora of the European part of the USSR, Academy of Sciences of the USSR. V.L. Komarov Botanical Institute, ed. by A.A. Fedorov. ) III, 191 (Leningrad: Nauka, 1978 (in Russian)

34. Flora of the USSR, Edited by Acad. V.L. Komarov, XXI, 704 (Moscow-Leningrad: Publishing House of the Academy of Sciences of the USSR, 1954) (in Russian)

35. V.S. Pashtetsky, O.B. Skipor, G.D. Kravchenko, O.M. Zolotilova, V.A. Zolotilov, E.F. Myagkikh, M.V. Verdysh, A.A. Popova, N.Y. Polyakova, A.V. Kolesnikov, Technologies of growing traditional and promising essential oil-bearing crops in the Republic of Crimea, 36 (Simferopol: IT "ARIAL", 2020) (in Russian) 